\title{
Man’s Interaction With Himself in The Old Man and the Sea With the View of Existentialism
}

\author{
LI Li-juan \\ Yibin University, Yibin City, China
}

\begin{abstract}
The Old Man and the Sea is Hemingway's last important work which is regarded by critics as the summary of his life and his philosophic views on life. The paper attempts to approach the story with the view of existentialism, which flourished at the time when Hemingway began to create this novella. In light of the existentialist views on the relations between being-in-itself and being-for-itself, and existence and essence, the author tends to analyze the interactions of the characters of the story with themselves through the choices they made, which is to be of significance for those who strive to understand Hemingway's work and who try to comprehend human beings and themselves.
\end{abstract}

Keywords: existentialism, interaction, being-in-itself, being-for-itself

\section{Introduction}

Published in 1952, The Old Man and the Sea won the year's Pulitzer Prize and directly led Earnest Hemingway to be the Nobel Prize laureate in 1954. He had a great effect on the development of modern American literature with his distinctive writing style characterized by its clipped dialogue and understatement. Many of his works are now considered classics of American literature.

Existentialism is a philosophical movement that posits individuals create the meaning and essence of their lives, as opposed to deities or authorities creating it for them. It is originated at the beginning of the twentieth century, which witnessed not only the development of technology and industry but the awakening of people's mind. The eruption of the First World War and the following economic crisis aroused man's suspicion of the authorities. Lost in this chaos man hardly believe in the political and economical rules of the society that he had followed for centuries, and formed a strong sense of insecurity about his existence. Thus existentialism, with the views that personal articulation of being is the only way to raise humanity's absurd condition out of much suffering and inevitable death, was born. It is believed that people are desperate to find out who and what they are throughout life as they make choices based on their experiences, beliefs, and outlook without the help of laws, ethnic rules, or traditions, and that each seeks the most individual freedom for people within a society.

During the time he prepared for The Old Man and the Sea, Hemingway was confronted with two factors which may have effects on his writing. One was that Hemingway created the story at the peak time of existentialism, and the other was that he personally underwent the falling period of his life when he began to probe into the meaning in man's existence; the result of both was that the story was to some degree colored with views of existentialism.

LI Li-juan, Master, Lecture, School of Foreign Languages, Yibin University. 


\section{Existences Precedes Essence}

By saying that existence precedes essence, existentialist Sartre means that man first of all exists, encounters himself, surges up in the world—and defines himself afterwards (Sartre, 1984, p. 6). It is in the course of one's existence that man chooses and defines himself as he wills. As far as man's existence and essence concerned, the terms "Being-in-itself" and "Being-for-itself" are the key issues which must be referred to. Sartre gave "existence" another synonym "Being" in his classic philosophic work Being and Nothingness where he thought of "Being is. Being is in-itself. Being is what it is." Being includes both Being-in-itself and Being-for-itself, but the latter is the subject of the former. Being-in-itself is Non-conscious Being. It is the Being of phenomenon and overflows the knowledge we have of it. As far as the man is concerned, Being-in-itself refers to the aspects of man who is what he is, including his face, his body, his skin, his ability to study, his accent, his capacity and all the things contained in him with actual objectiveness. Being-for-itself is the one appearing in our mind or consciousness, which does not really exist now, the one we want or image to be in the future, and the one we depict as if we are. In general, Being-in-itself is what we are and Being-for-itself is what we hope to be. Based on his In-itself, man has an For-itself in his mind to encourage him to work toward, which in turn helps to set up another new In-itself. Existing in this continuous transcendence man grows and defines himself. Instead of simply being, as the object-in-itself does, man, as an object-for-itself, actuate the intimate interaction with himself through the transcendence between his being-in-itself and being-for-itself.

By saying that existence precedes essence Sartre means that man first of all exists and defines himself afterwards, thus man's existence is the substantial condition for man's essence. Existence is not only the lasting transcendences between the In-itself and For-itself but also the "self-making-in-a-situation” (Sartre, 1984, p. 37). The fundamental contribution of existential thought lies in the idea that one's identity is constituted neither by nature nor by culture, since to "exist" is precisely to constitute such an identity. Man is nothing else but what makes of himself out of his existence with freedom. It is freedom that is the foundation of all essences, as only a man with freedom could exist with choices and make his own possibilities. Every one has his rights and freedom to choose what he wants to be in future.

Each one in this world exists in order to make and find his or her essence. In The Old Man and the Sea, it depicts an old man, who had not gotten any fish for eighty-seven days, fishing again on the sea, getting a marlin after three days and nights' fight, only to fail preventing it from the attack of sharks, and coming back to the shore with nothing but the skeleton of the marlin. It is disastrous for the old man to lose his fish which he spared no efforts to get in those three days with little fulfilling and rest, but instead of dropping himself to the destroy he went back to his shack and dreamed the lion as usual. It is believed that the story does not just present an old man's desperate fishing but symbolically a process of man's life, during which man interacts with himself by making his essence in the situations of his existence.

\section{The Old Man’s Self-transcendence}

The old man Santiago, existing in the world, according to his wills chose himself at every turning of his life and made his own essence, which was the exact transcendence between his Being-in-itself and Being-for-itself. The old man actuated his interaction with himself through the choices he made on himself and on friends. 


\section{His Choices on Himself}

Among the choices the old man made for his essence, his choice of being a fearless fisherman was the fundamental one. The old man Santiago, as told, lived in a town near the sea, and like all the other men of the town he also chose to live on fishing, no matter what age he had arrived at and how little blessing he got from God. Hemingway did not give the exact age of the man, but just called him an old man or his name Santiago. In fact, we could get his age from the clue in his cramped hands in the text to know that he is really old, which means that he is no longer suitable to take an energy-consuming work, let alone do the work of fishing which acquires quite a lot of physical energy and strength. The old man, however, still picked fishing as his way of living, because in his interaction with himself he had already made his own for-itself from the in-self of a fisherman. In his for-itself he expected riding his boat, shipping on the sea, and doing his fishing for all the rest of his life. That was the right for-itself equal to the value of his life and thus he did in actual. Striking to the career of fishing, he never thought of giving up.

It seemed at the start of the story that the old man was abandoned by God's blessing. The other villagers of the town considered him as a symbol of misfortune and escaped from him as far as possible. They even stopped his friend the boy from helping him by forcing the boy to fish on another boat. All of these were the situations of the old man's in-itself: without any catching, any fortune, any help, whereas in his for-itself he still clung to fishing by himself. So the next early morning he set out again. To be a fisherman was always there in the consciousness of the old man, so no matter how old he was and how much he was doomed, he still stood firmly at his skiff in his in-itself for the one in his for-itself. In the interaction with himself the old man decided to keep the career of being a fisherman, and through his activities he made one part of his essence. Confronted with his consciousness of being, the old man actuated his being with braveness, perseverance and resolution, and only in this way could he orientate his now being toward the one in his For-itself. Fortunately he did well in uniting his Being-for-itself and Being-in-itself, and kept to his spirits for all his life. That was the time he said "man is not made for defeat. A man can be destroyed but not defeated" and with resolution he fought to the last minute when the marlin was bitten out.

It is believed that dream is the reflection of one's inner thought. According to Freud, dream is the embodiment of one's sub-consciousness. In the story the old man dreamed about nothing but lions. When the old man felt lonely and needed some encouragement, he would hope to have a lion come to his dream. At the end of the story after he came back from the sea, the old man "was dreaming about lions" (Hemingway, 1976, p. 124). The frequent appearances of lions in the old man's dreams illuminated that the old man had the will to live as the lions did, and lion could be thought of as a symbol of the old man's spirits. With the firmed spirit and his hard working and he got back the respect from the people of the village. At the beginning of the story it was told that the old man was dumped for his bad luck by other villagers, except for the boy. The poor man, old and alone, without a catch for eight-four days, went back to the memory of his old days instead of getting involved in their mock and arrogance. Hard life though he lived at that time, the old man did not abandoned himself nor felt any shame before the other villagers. With the sense of pride and confidence about himself, the old man went to the sea on his own again, only to get nothing but a skeleton of a marlin. This time, however, he lost his fish but won back respects and concerns of other people of the town. People were looking for him during the days he did not come back, and there was a Pedrico (Hemingway, 1976, p. 121) helped him with looking after the skiff and gear after he came back. Evidently through his choices the old man made him being respected and built what he was. 


\section{The Old Man's Choices on Friend}

Each one in his consciousness has an image of what a friend should be like. Friend is the one with whom one shares his interests, feelings, faiths, and the one who is close to him in his For-itself not just in In-itself. The choosing of a friend to some degree is the result of man's interaction with himself and is decisive for one's actuating of himself. The old man regarded and treated the boy of the town Malolin, with whom he could not only communicate but also help to group and define himself, as his friend, as the Chinese old saying demonstrates we can know a person through his friends. Personalities of one's friends in some way could reflect one's choices on the characters of one's own.

The old man chose the boy, who was so different from him in their ages and experiences, as his friend, taught him, talked with him and trusted him. So when they were departed, the old man fell into a deep sorrow of missing. He talked to himself many times that he needed the boy to be by his side when he was fighting alone with the marlin on the far sea. The boy and the old man also share the same feeling when fishing. Once they got the female marlin of a couple, they saw the other male marlin's mental suffer which was shown in his unwillingness to leave from their boat. At that time "that was the saddest thing I ever saw with them, the old man thought. The boy was sad too" and this may explain why they could become friends. Being with the boy, who was as brave and determined as him, the old man got close to himself. With him, the old man had a soul companion on the way of making his essence.

The old man in the interaction with himself and in the transcendence between For-itself and In-itself made him what he was and actuated his being through the choices he made on himself and on his friend, including the choices of being a fisherman, inclining to the dreams of lions, keeping respectable grace, and making fiends with Marolin.

\section{The Boy Malolin's Freedom on Himself}

One constitutes one's being in the interaction with himself as he transcends his consciousness from one to another. According to existentialists, one's Being-for-itself or one's consciousness about oneself is free. In actual life this flux of consciousness could be embodied on the choices people have made, and each individual is free to make choices to build him the one he or she wants to be. Apart from the limitation on him, the boy Malolin still made the choices in accordance with his consciousness to be the one he wanted to be. Thus it was seen in the story that he chose the old man as his friend, made decisions on his parents' order and made himself the kind of people he wanted to be.

The boy's decisions or the choices he made for himself had created the one he was. No matter whether he was willing to do those decisions, during the time he did the selection he was interacting with himself and actuating his being. His words and acts revealed some parts of his being in some way. Since the old man did not get a fish for forty days the boy's parents ordered him to another lucky boat. The boy decided to follow his parents' order not to fish with the old man, through which he made himself a filial son. Although he could not go with the old man for fishing, he tried to help him within his ability, which made him a faithful friend. He still respected and cared about his friend the old man. His concern on the old man leaked from those words. Knowing the old man had no food for supper, the boy managed to get one for him because he knew that the old man would go to the sea for fishing the next day.

Through his choices the boy recognized his identities as a son and as a friend. Nevertheless, those 
identities sometimes were contradicted, which brought the boy his Facticity. ${ }^{1}$ As "the facticity of freedom is the fact that freedom is not able to be free" (Sartre, 1999, p. 630), the boy was not always free to choose as he willed. Since the boy lived in a society, with his parents, he had his facticity on his freedom. He had to leave from the old man's boat and helped on another lucky boat as his parents wished. He made the choice, through which he made him what he was, although what he was at that time was not the one he wanted to be.

The boy had the inclination to fish with the old man, while his parents and other fishermen did not thought this was good for him and kept him away from the old man. Before them, and in his situation, the boy had no choices at that moment but to follow their plan. In terms of existentialism, the boy admitted his In-itself, and he obeyed his parents, yet he still could not helping recovering his For-itself, because he always kept the consciousness that he was the old man's friend and he would never leave that poor man. So he still kept checking whether the old man had come back yet when the old man was on the sea. At last the old man came back, "the boy saw that the old man was breathing and then he saw the old man's hands and he started to cry" (Hemingway, 1976, p. 119). At his crying the boy overcame his limitations, realized what he really wanted, made his choice and said "Now we fish together again" (Hemingway, 1976, p. 122). Transcending between his For-itself and In-itself the boy underwent the interaction with himself. Through all the choices the boy actuated his being, and made him come back to the one he wanted to be.

\section{Conclusion}

In The Old Man and the Sea, the old man actuated his being and his interaction with himself through each of his choices and acts. His determination on his career, his personalities, his dreams and his choice on friend contributed to building him into the man called Santiago. The boy underwent the intimate interaction with himself and actuated his being through his decisions to be his possibilities, and the fishermen also managed to realize their possible styles of being through their behaviors and choices. The characters of the story through the choices and decisions they made explained man's interaction with himself and actuated their being among the transcendence between their In-itself and For-itself, by which the understanding of man's existence is strengthened.

Interpreting Hemingway's greatest work The Old Man and the Sea from the perspective of existentialism, the author of this paper restates the literal beauty and inspiring spirit conveyed in the story. Many critics have compared the meanings of the story as a iceberg, the surface of which is limited and obvious. With the views of existentialism, the meanings under the surface began to beam to the sincere readers, leading them to ponder about the philosophic power of literature and real significance their own lives.

\section{References}

Baker, C. (1972). Ernest Hemingway: A life story. England: Penguin Books Ltd. Hemingway, E. (1976). The old man and the sea. Frogmore, St Albans: Triad/Panther Books.

Nietzsche, F. (1967). The will to power. (W. Kaufamann \& R. J. Hollingale, Trans.). New York: Random House.

Sartre, J. P. (1984). Existentialism and humanism. (P. Mairiet, Trans.). New York: Haskell.

Sartre, J. P. (1999). Being and nothingness. (Translated and with an introduction by H. E. Brnes). Beijing: China Social Science Publishing House.

\footnotetext{
${ }^{1}$ Facticity: a term used in the explanation of existentialism means limitation or restrict of one's freedom.
} 